Abstracta Iranica Iranica

Revue bibliographique pour le domaine irano-aryen

Volume 32-33 | 2013

Comptes rendus des publications de 2009-2010

\title{
Aḥmad 'Alī Asadī. Olgū-ye esteqrārī va kārbordī dar dašt-e Bastak, Hormozgān
}

\section{Rémy Boucharlat}

\section{(2) OpenEdition}

1 Journals

Édition électronique

URL : http://journals.openedition.org/abstractairanica/40454

DOI : 10.4000/abstractairanica.40454

ISSN : 1961-960X

\section{Éditeur :}

CNRS (UMR 7528 Mondes iraniens et indiens), Éditions de l'IFRI

\section{Édition imprimée}

Date de publication : 1 décembre 2013

ISSN : 0240-8910

\section{Référence électronique}

Rémy Boucharlat, «Aḥmad 'Alī Asadī. Olgū-ye esteqrārī va kārbordī dar dašt-e Bastak, Hormozgān », Abstracta Iranica [En ligne], Volume 32-33 | 2013, document 137, mis en ligne le 01 juillet 2016, consulté le 03 octobre 2020. URL : http://journals.openedition.org/abstractairanica/40454; DOI : https://doi.org/10.4000/abstractairanica.40454

Ce document a été généré automatiquement le 3 octobre 2020.

Tous droits réservés 


\title{
Aḥmad 'Alī Asadī. Olgū-ye esteqrārī va kārbordī dar dašt-e Bastak, Hormozgān
}

\author{
Rémy Boucharlat
}

\section{RÉFÉRENCE}

Aḥmad 'Alī Asadī. « Olgū-ye esteqrārī va kārbordī dar dašt-e Bastak, Hormozgān » (The Settlement Patter and Land Use in Bastak Plain, Hormozgān Province), Majalleh bāstānshenāsī va tärïkh (Iranian Journal of Archaeology and History). Vol. 23/1, Serial No. 45, Autumn 2008-Winter 2009[2010]/1387, p. 3-31. (English Summary p. 1)

1 Vallée de basse altitude dans les garmsirrs, Bastak est située au sud de Lār, à environ $50 \mathrm{~km}$ de la côte du golfe Persique. Tout le sud de l'Iran a été peu exploré. La prospection de l'A. montre la très faible occupation des millénaires précédant l'époque achéménide, une demi-douzaine de sites pour cette époque, mais surtout une forte augmentation à l'époque parthe et un pic remarquable à l'époque sassanide, quand est créé un fort réseau d'irrigation. Si l'occupation se poursuit à l'époque islamique, elle semble moins intense (diagramme fig. 23), ce qui reste à expliquer. Une fois de plus, le rôle des techniques d'irrigation semble primordial.

\section{AUTEURS}

RÉMY BOUCHARLAT

CNRS, Lyon 